\title{
IMITATION MODELING FOR THE PURPOSE OF FORMATION OF THE OPTIMUM ASSORTMENT SALES POLICY
}

Irina Atyunkina ${ }^{1}$

Alexey Kirpikov ${ }^{2}$

\begin{abstract}
Within the framework of the scientific work, the algorithm for formation of an optimal mix of the sold commodity items in the conditions of managing the risk of changing the capital structure and obtaining the required effectiveness of the financial and economic activity of an economic entity is investigated. A methodological algorithm for solving the problem is proposed using the tool of simulation modeling. Consideration of alternative approaches to financing the structure of commodity stocks of an organization taking into account possible scenarios of changing market conditions determining the efficiency of the company's operating activities served as the target for the

the simulation model. Justification of the author's position on the specific features of the solution of the problem posed stipulated the inclusion in the methodological algorithm of the basics of $\mathrm{ABC}-\mathrm{XYZ}$ analysis, as well as the VAR toolkit. Analytical processing of the results was based on the interpretation of descriptive statistics indicators, the most important of which was the share of experiments demonstrating the possibility of maintaining the required margin of financial strength, as well as the absolute amount of profit before tax, obtained as a result of the mathematical expectation of profit in conditions of optimistic, probable and pessimistic scenarios.
\end{abstract} formation of an array of simulation experiments. Based on the provisions of the corporate finance theory, a functional relationship was established between the productive and factor characteristics of
Keywords: simulation modeling, financial stability, scenario analysis, financing strategies, $\mathrm{ABC}-\mathrm{XYZ}$

\footnotetext{
${ }^{1}$ Kazan Federal University, Institute of Management, Economics and Finance, Kazan, 420008, Russia

${ }^{2}$ Kazan Federal University, Institute of Management, Economics and Finance, Kazan, 420008, Russia
} 


\section{Periódico do Núcleo de Estudos e Pesquisas sobre Gênero e Direito \\ Centro de Ciências Jurídicas - Universidade Federal da Paraíba \\ V. 8 - No 04 - Ano 2019 - Special Edition}

ISSN | 2179-7137 | http://periodicos.ufpb.br/ojs2/index.php/ged/index

analysis, VAR methodology, assortment sales policy.

\section{Introduction}

In applied economic science, the development of methods for the effective management of financial sustainability is often limited solely to monitoring key economic indicators of the status of the company and the basics of forming its financing strategies. Such approach does not allow the task in full to realize, since multistage methodological algorithms combining economic-mathematical and calculationanalytical tools are needed to achieve it. The generalization of methodical techniques presented in specialized literary sources and subjected to author's interpretation in the context of the specifics of the task posed allows an integrated financial stability management system within the assortment sales policy to develop.

\section{Methods}

The research was based on the results of application of traditional financial indicators, identification of scenarios for the development of events in the operations of an economic entity
[7, 8, 9] and various strategies for financing the purchase of goods. In addition, $\mathrm{ABC}-\mathrm{XYZ}$ analysis [4] was used in the work, which application is necessary to identify the most important commodity items for the company, as well as the processing of the forecast data used in the course of building the simulation model $[3,6,10]$ using methodology VAR [1, 2, 5], which gained considerable popularity in the process of corporate finance management.

\section{Results}

The algorithm of the original author's compilation of methodological approaches with an independent status, but combined with the purpose of solving a specific management problem, is presented in the paper.This set of instructions describing the order of actions, allows us to form the optimal assortment sales policy for a trading company. The proposed algorithm is based on the solution of the following problem: "To determine the amount of additional sources needed to finance the purchase of goods in terms of their payback within three months, with the organization's striving to get the 
maximum possible amount of the aggregate financial result with establishing an acceptable level of risk".
The main stages of the developed algorithm are detailed in Figure 1.

Collect all the necessary information on prices and sales volumes, commercial and variable expenses, the amount of equity capital, commodity positions, etc. for previous periods

Conduct an $\mathrm{ABC}-\mathrm{XYZ}$ analysis of the cumulative marginal revenue based on the calculated average forecast values, as well as the calculation of turnover for each commodity item

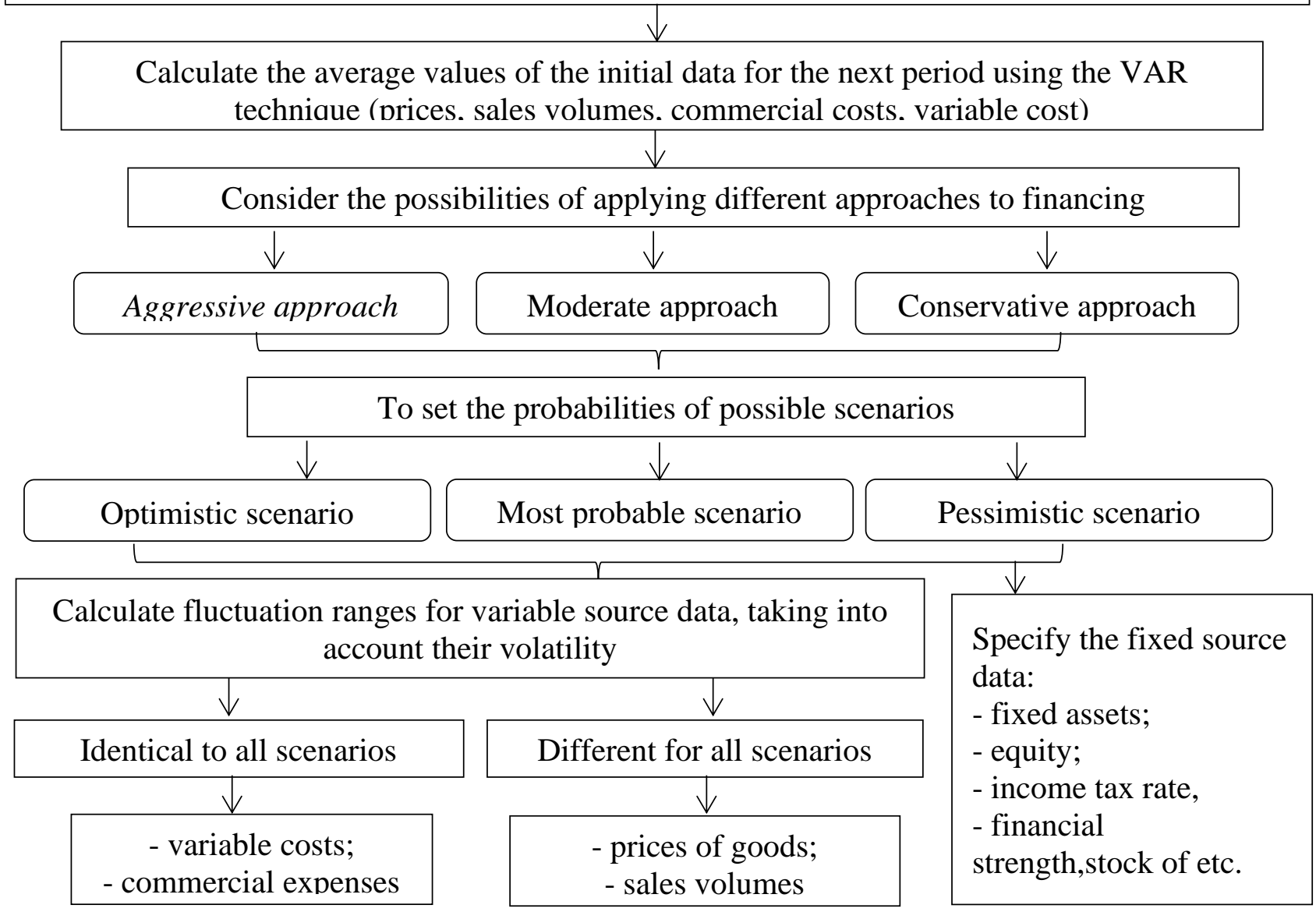

\begin{tabular}{|c|}
\hline Conduct simulation modelling \\
$\downarrow$ \\
$\begin{array}{c}\text { Analyze indicators of descriptive sales statistics and form an } \\
\text { assortment policv }\end{array}$ \\
\hline
\end{tabular}

Fig. 1. Algorithm of analytical justification of the sales policy 
Preparation for simulation is a complex work package which includes several key steps.

At the first stage, there should be obtained all the required information which serves in the capacity of the initial basis for building the simulation model and conducting the analysis. Information sources for the collection of data such as prices and sales volumes, commercial and variable expenses, commodity positions, etc., are the accounting financial and management reporting of the business entity, as well as consolidated operational records for previous periods.

The second stage of the preparatory work stage is the conduct of a comprehensive analysis of available commodity items. In the event that the economic entity sells disparate goods, they should initially be grouped together by the same characteristics with the aim of their possible comparison with similar ones. The authors suggest using the following indicators as the key evaluation criteria: aggregate margin income determined as a result of $\mathrm{ABC}$ analysis; the volatility of sales calculated in the course of XYZ-analysis, and the period of turnover for each commodity item.

The calculation of the predicted mean values and ranges of their changes, which will become the basis for building a simulation model, is proposed to implement using the VAR methodology. The complex structure designing of the model includes consideration of various financing strategies and variants of the development of events. Conservative, moderate and aggressive approaches are suggested as the main approaches to financing. The difference between these approaches lies in the financing of a different number of items of purchased goods and their volumes with their inherent characteristics. For example, the financing of all goods is characteristic for an aggressive approach, except for those that have negative marginal revenue. The conservative approach is characterized with financing of goods with constant and periodic demand, with the exception of those that have a low turnover and cost-effectiveness ratio. Three alternative scenarios for the development of events are considered within each financing strategy: 
optimistic, most probable and pessimistic, with specific for each price and projected sales volume.
55

An important step in the preparation for building the simulation model is the formation of a system of indicators (Figure 2).

\section{Indicators used in the group}

own capital, non-current assets, the minimum value of the differential of the financial leverage, the rate of profit tax

prices for goods and their forecast sales volumes

the number of the names of goods purchased, and the number of the names of goods for which only balances from the previous period will be sold

Fig. 2. Initial data for the simulation modeling

Analytical indices calculated in the course of simulation experiments can also be assigned to a separate group.

Having developed the structure of the simulation model and having prepared all the required information, an analyst can move to the next stage of the work, which is the key one - the simulation. The building of the simulation model is implemented with the use of the software application package Microsoft Excel. This stage is quite laborious, and for the purpose of more clear visual representation the simulation process is schematically shown in Figure 3.

Figure 3 is quite informative and describes the process of building a simulation model in complex. The simulation model consists of a large number of experiments, in our case 1000 for each approach, which model possible situations of events with randomly selected initial data set in a system of indicators with fixed values or ranges of changes. An increase in the number of 
experiments conducted will contribute to an increase in the accuracy of the combined results. Based on randomly selected initial data for each experiment, analytical indicators are calculated and a decision is taken to attract additional sources of financing, based on checking data describing the results of building the simulation model using the example of a moderate financing strategy with an optimistic scenario. the preservation of the minimum value of the differential of the financial leverage and the possibility of repaying the loan while maintaining an acceptable level of financial stability of the company. Table 1 presents a fragment of the calculated

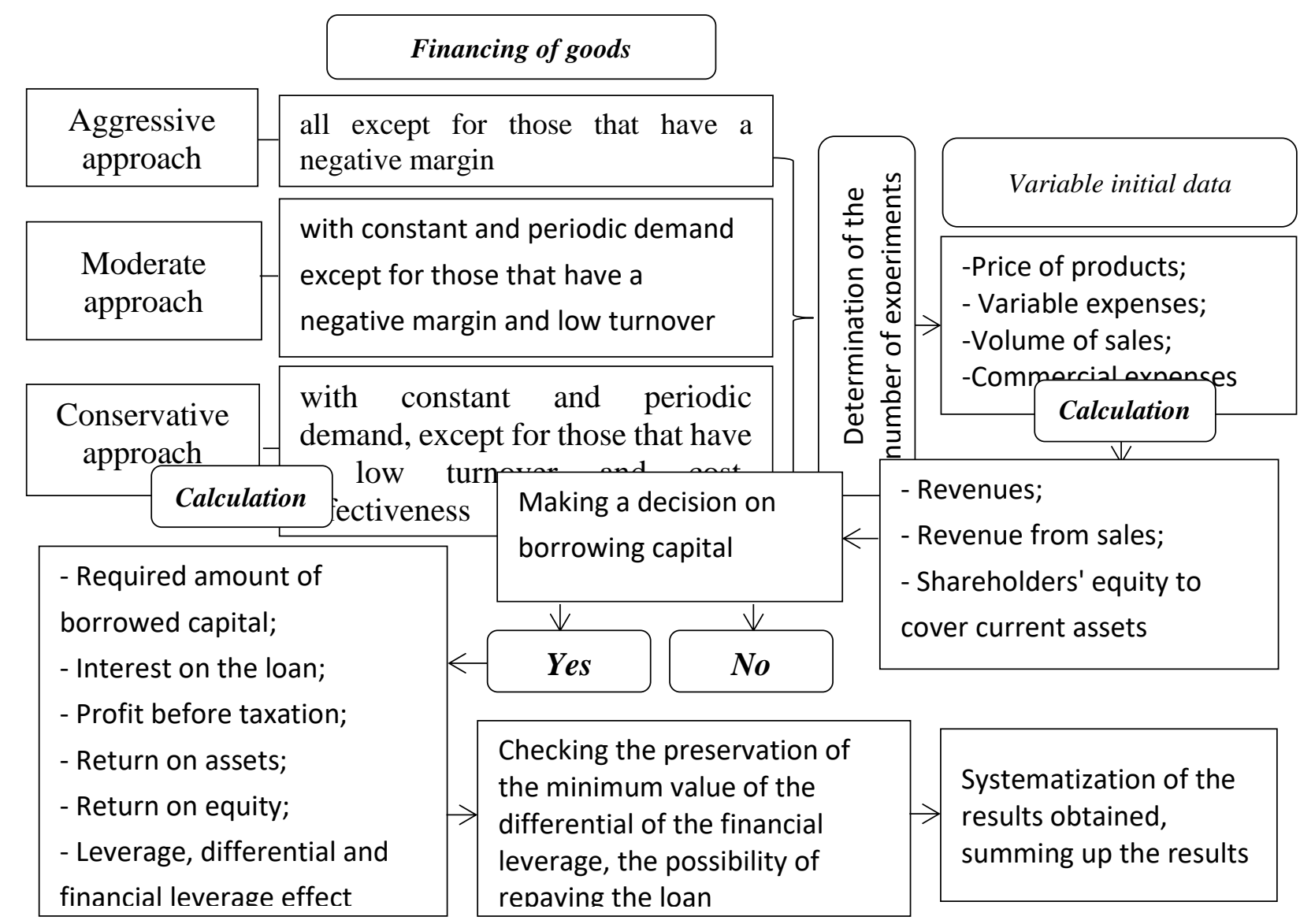

Fig. 3. The simulation modeling process 
Periódico do Núcleo de Estudos e Pesquisas sobre Gênero e Direito Centro de Ciências Jurídicas - Universidade Federal da Paraíba

V. 8 - No 04 - Ano 2019 - Special Edition ISSN | 2179-7137 | http://periodicos.ufpb.br/ojs2/index.php/ged/index

Table 1: A generalized algorithm for the format of initial data and results presentation for simulation modeling using the example of a moderate approach with an optimistic scenario of events

\begin{tabular}{|c|c|c|c|c|c|c|}
\hline \multicolumn{2}{|c|}{ Indicator name } & $\begin{array}{c}\text { Letter } \\
\text { designation }\end{array}$ & $\begin{array}{c}\text { Experiment } \\
1\end{array}$ & $\begin{array}{c}\text { Experiment } \\
2\end{array}$ & $\ldots$ & $\begin{array}{c}\text { Experiment } \\
\mathrm{n}\end{array}$ \\
\hline \multirow{3}{*}{$\begin{array}{c}\text { Sale } \\
\text { under the } \\
\text { forecast }\end{array}$} & $\begin{array}{l}\text { Prices, USD } \\
\text { (per item) }\end{array}$ & $\mathrm{Ii}$ & 316 & 319 & & 317 \\
\hline & $\begin{array}{l}\text { Variable } \\
\text { costs, USD } \\
\text { (per item) }\end{array}$ & $\mathrm{Ii}$ & 238 & 238 & & 238 \\
\hline & $\begin{array}{l}\text { Number of } \\
\text { goods sold, } \\
\text { USD (per } \\
\text { item) }\end{array}$ & Ii & 1294 & 1304 & & 1225 \\
\hline \multirow{3}{*}{$\begin{array}{l}\text { Sale of } \\
\text { balances }\end{array}$} & $\begin{array}{l}\text { Prices, USD } \\
\text { (per item) }\end{array}$ & Ii & 177 & 178 & & 176 \\
\hline & $\begin{array}{l}\text { Variable } \\
\text { costs, USD } \\
\text { (per item) }\end{array}$ & $\mathrm{Ii}$ & 200 & 200 & & 200 \\
\hline & $\begin{array}{l}\text { Number of } \\
\text { goods sold, } \\
\text { USD (per } \\
\text { item) }\end{array}$ & Ii & 240 & 240 & & 240 \\
\hline \multicolumn{2}{|c|}{ Total revenue, USD } & $\mathrm{R}$ & 2386880 & 2449129 & & 2412554 \\
\hline \multicolumn{2}{|c|}{$\begin{array}{l}\text { Commercial expenses, } \\
\text { USD (per item) }\end{array}$} & Oi & 733342 & 756327 & & 743597 \\
\hline \multicolumn{2}{|c|}{$\begin{array}{l}\text { Total profit from sales, } \\
\text { USD }\end{array}$} & $\mathrm{R}$ & 306,962 & 315,851 & & 314436 \\
\hline \multicolumn{2}{|c|}{$\begin{array}{l}\text { Own capital, going to } \\
\text { cover current assets, }\end{array}$} & $\mathrm{F}$ & 450000 & 450000 & & 450000 \\
\hline
\end{tabular}


Periódico do Núcleo de Estudos e Pesquisas sobre Gênero e Direito Centro de Ciências Jurídicas - Universidade Federal da Paraíba

V. 8 - No 04 - Ano 2019 - Special Edition ISSN | 2179-7137 | http://periodicos.ufpb.br/ojs2/index.php/ged/index

\begin{tabular}{|c|c|c|c|c|c|}
\hline \multicolumn{2}{|c|}{$\begin{array}{l}\text { Quantity of goods left in } \\
\text { the warehouse, units. (by } \\
\text { element) }\end{array}$} & Phi & 43 & 43 & 43 \\
\hline \multicolumn{2}{|c|}{$\begin{array}{l}\text { Minimum quantity of } \\
\text { goods purchased, units } \\
\text { (by element) }\end{array}$} & $\mathrm{Pi}$ & 1316 & 1326 & 1244 \\
\hline \multicolumn{2}{|c|}{$\begin{array}{l}\text { Required amount of } \\
\text { borrowed capital, USD }\end{array}$} & $\mathrm{R}$ & 815,611 & 847505 & 823953 \\
\hline \multicolumn{2}{|c|}{$\begin{array}{l}\text { Average annual interest } \\
\text { rate on the loan, } \%\end{array}$} & $\mathrm{~F}$ & 16 & 16 & 16 \\
\hline \multicolumn{2}{|c|}{$\begin{array}{l}\text { Interest on the loan for the } \\
\text { whole term, USD }\end{array}$} & $\mathrm{R}$ & 32,624 & 33900 & 32958 \\
\hline \multicolumn{2}{|c|}{$\begin{array}{l}\text { Total profit before tax, } \\
\text { USD }\end{array}$} & $\mathrm{R}$ & 274338 & 281951 & 281478 \\
\hline \multirow{4}{*}{$\begin{array}{l}\text { Analytical } \\
\text { indicators }\end{array}$} & $\begin{array}{l}\text { Financial } \\
\text { Leverage }\end{array}$ & $\mathrm{R}$ & 1.48 & 1.54 & 1.50 \\
\hline & $\begin{array}{l}\text { Return on } \\
\text { assets, } \%\end{array}$ & $\mathrm{R}$ & 28.94 & 28.91 & 29.42 \\
\hline & $\begin{array}{l}\text { Differential } \\
\text { of the } \\
\text { financial } \\
\text { leverage, } \\
\text { percentage } \\
\text { points }\end{array}$ & $\mathrm{R}$ & 24.94 & 24.91 & 25.42 \\
\hline & $\begin{array}{l}\text { Preservation } \\
\text { of the } \\
\text { minimum } \\
\text { value of the } \\
\text { differential, } \\
\text { "YES" / } \\
\text { "NO" }\end{array}$ & $\mathrm{R}$ & YES & YES & YES \\
\hline
\end{tabular}




\begin{tabular}{|l|l|c|c|c|c|c|}
\hline & $\begin{array}{l}\text { Effect of } \\
\text { financial } \\
\text { leverage, }\end{array}$ & $\mathrm{R}$ & 29.59 & 30.71 & 30.46 \\
\cline { 2 - 6 } & $\begin{array}{l}\text { Return on } \\
\text { equity,\% }\end{array}$ & $\mathrm{R}$ & 52.75 & 53.84 & 54.00 \\
\hline
\end{tabular}

The letters in each line should be interpreted as follows: "Ii" - the ranges of the indicator values change are different in each scenario, "Oi" - the ranges of the indicator values change are the same in all development scenarios, "P / $\mathrm{Pi}^{\prime}$ is the data received by the calculated way, "F/ Fi " - the value of the indicator is fixed for all experiments. The lines, in the names of which the phrase "by elements" is present, presume the examination of prices, variable expenses, the quantity separately for each commodity item, commercial expenses for elements of costs, such as: rent of premises and equipment, transportation costs, labor costs, communication services and etc.

Similarly, the remaining tables are formed considering all possible strategies for financing purchases of goods and scenarios. In order to simplify the collection of the results and form a single summary table, it is recommended that all calculations be made in the same format.

\section{Summary}

It is most convenient to summarize the results in a tabular form structuring the results separately for each scenario of events development within the framework of a specific approach with a view to their possible comparison and identifying an appropriate strategy for financing the purchase of goods. A fragment of the final indicators of the simulation model is shown in Table 2.

Table 2 :A part of the simulation modeling results

\begin{tabular}{|c|c|c|c|}
\hline $\begin{array}{c}\text { Indicator } \\
\text { name }\end{array}$ & Aggressive approach & Moderate approach & $\begin{array}{c}\text { Conservative } \\
\text { approach }\end{array}$ \\
\hline
\end{tabular}


Periódico do Núcleo de Estudos e Pesquisas sobre Gênero e Direito Centro de Ciências Jurídicas - Universidade Federal da Paraíba V. 8 - No 04 - Ano 2019 - Special Edition ISSN | 2179-7137 | http://periodicos.ufpb.br/ojs2/index.php/ged/index

\begin{tabular}{|c|c|c|c|c|c|c|c|c|c|c|c|c|c|}
\hline & $\begin{array}{l}\text { O. } \\
\text { S. }\end{array}$ & $\begin{array}{c}\text { MP } \\
\text { S. }\end{array}$ & P.S & $\begin{array}{l}\text { Tot } \\
\text { al }\end{array}$ & $\begin{array}{l}\text { O. } \\
\text { S. }\end{array}$ & $\begin{array}{c}\text { MP } \\
\text {.S. }\end{array}$ & P.S & $\begin{array}{l}\text { Tot } \\
\text { al }\end{array}$ & $\begin{array}{l}\text { O. } \\
\text { S. }\end{array}$ & $\begin{array}{c}\text { MP } \\
\text {.S }\end{array}$ & $\begin{array}{c}\text { P.S } \\
\text {. }\end{array}$ & $\begin{array}{l}\text { Tot } \\
\text { al }\end{array}$ \\
\hline \multirow{6}{*}{ 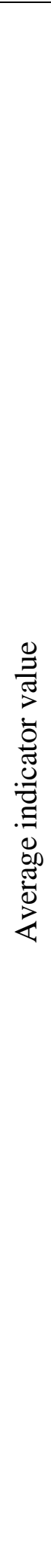 } & $\begin{array}{l}\text { Return, } \\
\text { thous. } \\
\text { dollars. }\end{array}$ & $\begin{array}{c}2 \\
674\end{array}$ & $\begin{array}{c}2 \\
432\end{array}$ & $\begin{array}{c}2 \\
186\end{array}$ & $\begin{array}{c}2 \\
382\end{array}$ & $\begin{array}{c}2 \\
424\end{array}$ & $\begin{array}{c}2 \\
193\end{array}$ & $\begin{array}{c}1 \\
959\end{array}$ & $\begin{array}{c}2 \\
146\end{array}$ & $\begin{array}{c}2 \\
024\end{array}$ & $\begin{array}{c}1 \\
834\end{array}$ & $\begin{array}{c}1 \\
648\end{array}$ & $\begin{array}{c}1 \\
797\end{array}$ \\
\hline & $\begin{array}{l}\text { Profit } \\
\text { from } \\
\text { sales, } \\
\text { thousan } \\
\text { d } \\
\text { dollars }\end{array}$ & 310 & 192 & 72 & 168 & 302 & 182 & 65 & 159 & 202 & 97 & -6 & 77 \\
\hline & $\begin{array}{l}\text { The } \\
\text { borrow } \\
\text { ed } \\
\text { capital } \\
\text { (withou } \\
\text { t\%), } \\
\text { thousan } \\
\text { d } \\
\text { dollars. }\end{array}$ & $\begin{array}{c}1 \\
090\end{array}$ & 962 & 829 & 934 & 837 & 721 & 599 & 695 & 521 & 432 & 347 & 416 \\
\hline & $\begin{array}{l}\text { Financi } \\
\text { al } \\
\text { leverag } \\
\text { e }\end{array}$ & $\begin{array}{c}1,9 \\
8\end{array}$ & $\begin{array}{c}1,7 \\
5\end{array}$ & $\begin{array}{c}1,5 \\
1\end{array}$ & 1,7 & $\begin{array}{c}1,5 \\
2\end{array}$ & $\begin{array}{c}1,3 \\
1\end{array}$ & $\begin{array}{c}1,0 \\
9\end{array}$ & $\begin{array}{c}1,2 \\
6\end{array}$ & $\begin{array}{c}0,9 \\
5\end{array}$ & $\begin{array}{c}0,7 \\
9\end{array}$ & $\begin{array}{c}0,6 \\
3\end{array}$ & $\begin{array}{c}0,7 \\
6\end{array}$ \\
\hline & $\begin{array}{l}\text { Return } \\
\text { on } \\
\text { assets, } \\
\%\end{array}$ & $\begin{array}{l}23, \\
23\end{array}$ & $\begin{array}{l}15, \\
92\end{array}$ & $\begin{array}{c}6,7 \\
3\end{array}$ & $\begin{array}{c}13 \\
8\end{array}$ & $\begin{array}{c}27 \\
9\end{array}$ & $\begin{array}{l}18, \\
89\end{array}$ & 7,7 & $\begin{array}{l}16, \\
32\end{array}$ & $\begin{array}{l}26 \\
36\end{array}$ & $\begin{array}{l}14, \\
37\end{array}$ & $\begin{array}{c}- \\
1,1\end{array}$ & $\begin{array}{l}10 \\
75\end{array}$ \\
\hline & $\begin{array}{l}\text { Differe } \\
\text { ntial of } \\
\text { the }\end{array}$ & $\begin{array}{l}19, \\
23\end{array}$ & $\begin{array}{l}11, \\
92\end{array}$ & $\begin{array}{c}2,7 \\
3\end{array}$ & 9,8 & $\begin{array}{c}23 \\
9\end{array}$ & $\begin{array}{l}14, \\
89\end{array}$ & 3,7 & $\begin{array}{l}12 \\
32\end{array}$ & $\begin{array}{l}22 \\
36\end{array}$ & $\begin{array}{l}10, \\
37\end{array}$ & $\begin{array}{c}- \\
5,1\end{array}$ & $\begin{array}{c}6,7 \\
5\end{array}$ \\
\hline
\end{tabular}


Periódico do Núcleo de Estudos e Pesquisas sobre Gênero e Direito Centro de Ciências Jurídicas - Universidade Federal da Paraíba V. 8 - $\mathrm{N}^{\circ} 04$ - Ano 2019 - Special Edition ISSN | 2179-7137 | http://periodicos.ufpb.br/ojs2/index.php/ged/index

\begin{tabular}{|c|c|c|c|c|c|c|c|c|c|c|c|c|}
\hline \begin{tabular}{|l|l} 
financi \\
al \\
leverag \\
e, \\
percent \\
age \\
points
\end{tabular} & & & & & & & & & & & & \\
\hline \begin{tabular}{|l} 
Effect \\
of \\
financi \\
al \\
leverag \\
e, $\%$
\end{tabular} & $\begin{array}{l}30, \\
51\end{array}$ & $\begin{array}{l}16 \\
69\end{array}$ & $\begin{array}{c}3,3 \\
1\end{array}$ & $\begin{array}{l}14, \\
08\end{array}$ & $\begin{array}{c}29 \\
13\end{array}$ & $\begin{array}{l}15 \\
62\end{array}$ & $\begin{array}{c}3,2 \\
4\end{array}$ & $\begin{array}{l}13, \\
31\end{array}$ & $\begin{array}{l}16, \\
97\end{array}$ & $\begin{array}{c}6,5 \\
4\end{array}$ & $\begin{array}{c}- \\
2,5 \\
5\end{array}$ & $\begin{array}{c}4,9 \\
3\end{array}$ \\
\hline $\begin{array}{l}\text { Return } \\
\text { on } \\
\text { equity, } \\
\%\end{array}$ & $\begin{array}{c}49 \\
1\end{array}$ & $\begin{array}{l}29 \\
43\end{array}$ & $\begin{array}{c}8,6 \\
9\end{array}$ & $\begin{array}{l}25 \\
12\end{array}$ & $\begin{array}{l}51, \\
45\end{array}$ & $\begin{array}{l}30 \\
73\end{array}$ & $\begin{array}{c}9,3 \\
9\end{array}$ & $\begin{array}{l}26 \\
37\end{array}$ & $\begin{array}{l}38, \\
06\end{array}$ & $\begin{array}{l}18 \\
04\end{array}$ & $\begin{array}{c}- \\
3,4 \\
3\end{array}$ & $\begin{array}{l}13 \\
53\end{array}$ \\
\hline $\begin{array}{l}\text { Profit } \\
\text { before } \\
\text { taxatio } \\
\mathrm{n}, \\
\text { thousan } \\
\text { d } \\
\text { dollars }\end{array}$ & 267 & 154 & 39 & 131 & 269 & 154 & 41 & 131 & 181 & 80 & -20 & 60 \\
\hline $\begin{array}{l}\text { Specific } \\
\text { weight of } \\
\text { experiments } \\
\text { with } \\
\text { preservation } \\
\text { of safety }\end{array}$ & $\begin{array}{c}0,1 \\
5\end{array}$ & $\begin{array}{c}0,4 \\
6\end{array}$ & 0 & $\begin{array}{c}0,6 \\
1\end{array}$ & $\begin{array}{c}0,1 \\
5\end{array}$ & 0,5 & 0 & $\begin{array}{c}0,6 \\
5\end{array}$ & $\begin{array}{c}0,1 \\
5\end{array}$ & $\begin{array}{c}0,2 \\
9\end{array}$ & 0 & $\begin{array}{c}0,4 \\
4\end{array}$ \\
\hline
\end{tabular}




\begin{tabular}{|c|c|c|c|c|c|c|c|c|c|c|c|c|}
\hline $\begin{array}{l}\text { factor on } \\
\text { differential }\end{array}$ & & & & & & & & & & & & \\
\hline $\begin{array}{l}\text { Specific } \\
\text { weight of } \\
\text { experiments } \\
\text { in which } \\
\text { profit before } \\
\text { tax is } \\
\text { positive }\end{array}$ & $\begin{array}{c}0,1 \\
5\end{array}$ & 0,5 & $\begin{array}{c}0,3 \\
5\end{array}$ & 1 & $\begin{array}{c}0,1 \\
5\end{array}$ & 0,5 & $\begin{array}{c}0,3 \\
5\end{array}$ & 1 & $\begin{array}{c}0,1 \\
5\end{array}$ & 0,5 & $\begin{array}{c}0,0 \\
4\end{array}$ & $\begin{array}{c}0,6 \\
9\end{array}$ \\
\hline
\end{tabular}

The letters denoting the column names are treated as follows: "OS" is an optimistic scenario, "MPS" is a probable scenario, "PS" is a pessimistic scenario. Forming this table on the basis of practice, it is recommended to calculate other indicators of descriptive statistics, such as maximum and minimum values, mode, median, etc. in addition to the average values in which most of the indicators are presented.

A comprehensive analysis of the results allows us to make a choice regarding the most optimal strategy for financing the purchase of goods and determine the amount of borrowed capital. Thus, the value of the pre-tax profit indicator, which characterizes the financial performance of the company, with an aggressive and moderate approach is located at around \$ 131 thousand, while at a conservative approach this indicator is more than half the amount. This is explained by smaller purchases and sales volumes than in other approaches. In addition, with a conservative approach, the specific weight indicator of experiments with preservation of the safety margin on the differential, the minimum value of which was taken at the level of $10 \%$, is much lower than for other approaches. The current situation can be explained by the fact that the return on assets under the conservative approach is at the level of $10.75 \%$, which is lower by 5.57 percentage points of the indicator obtained with a moderate approach, and by 3.05 percentage points - with an aggressive approach. Thus, with a decrease in the profitability of assets for an unchanged average three-month 
interest rate, the differential of the financial lever with a conservative approach in most cases does not withstand the minimum required value.

Analyzing the financial leverage, you can see that with an aggressive strategy, this indicator is 0.44 points higher than the leverage value calculated with a moderate approach to attracting borrowed sources of financing, which indicates a greater dependence of the company on creditors, and, consequently, on risk.

In the example considered, in our opinion, it is more rational to apply a moderate strategy to financing the purchase of goods, which represents the best correlation between the accepted risk and the financial performance obtained. Thus, the average size of attracted borrowed sources will vary from \$ 599 to \$ 837 thousand.

\section{Conclusion}

Thus, the construction of an algorithm with the use of a comprehensive approach and the integration of elements of methodological tools in the formation of the assortment sales policy allows us to go beyond the traditional financial diagnostics of an organization and create prerequisites for effective business administration aimed at achieving a compromise between the performance and financial stability of the economic entity.

\section{Acknowledgments}

The work is carried out according to the Russian Government Program of Competitive Growth of Kazan Federal University.

\section{References}

Abad, P., Benito, S., López, C. (2014) A comprehensive review of Value at Risk methodologies. Spanish Review of Financial Economics. 12 (1), pp.15-32.

Allen, S. (1997) Comparing and contrasting different approaches to computive value at risk. Risk Conference.

Antonelli, S., Iovino , M.G. (2002) Optimization of Monte Carlo procedures for value at risk estimates.Economic Notes. 31 (1), pp.59-78.

Dhoka, D.a (2015) Challenges with multi-dimensional inventory 


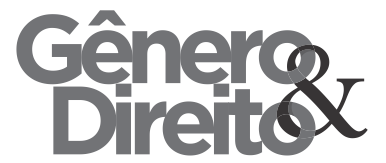

Periódico do Núcleo de Estudos e Pesquisas sobre Gênero e Direito Centro de Ciências Jurídicas - Universidade Federal da Paraíba

V. 8 - No 04 - Ano 2019 - Special Edition ISSN | 2179-7137 | http://periodicos.ufpb.br/ojs2/index.php/ged/index classifications and optimization. Asian Social Science. 11 (4), pp.365-370.

Duffie, D., Pan, J. (1997) An overview of value at risk. Journal of Derivatives. 4 (3). pp. 7-49.

Dyson, R.G., Shale, E.A. (2010) Data envelopment analysis, operational research and uncertainty. Journal of the Operational Research Society. 61 (1). pp. 25-34.

Eppen, Gary D., Matin, R. Kipp, Schrage, Linus (1989) Scenario. Operations Research. 37 (4). pp. 517 527.

Huss, W.R., Honton E.J. (1987) Scenario planning -What style should you use? Long Range Planning.20 (4). pp. 21-29.

Jamshidian, F., Zhu, Y. (1997) Scenario simulation: Theory and methodology. Finance and Stochastics , 1, pp.43-67.

Majewski, G.M., Delak, B., Damij, N. (2014) TK business process simulation: A case study with a Slovenian highachieving company from the SME sector. Proceeding of the European
Conference on Knowledge Management, ECKM. 2. pp.593-608 